\title{
USE OF SONGS IN TEACHING SIMPLE TOBE AND PAST TENSE
} TEACHING

\section{Paula L. Hampp}

\begin{abstract}
The purpose of this study was to see whether the use of English songs can improve students' understanding and mastery of Simple and Past Tense in affirmative sentences, denying and questioning sentences. And to prove that songs are also effective in increasing students' abilities in mastery 'To Be' Benefits of research. The results of the study are expected to be useful for researchers, students, lecturers and academics: Firstly, This research is expected to be useful for researchers to know precisely the conditions of the field, the problem of the learning process so that it becomes a reference in preparing before facing the actual conditions. Secondly, For students, the use of this method is expected to help them understand the lesson more easily and make them like English because the use of this method is fun. Thirdly, for readers, you will get information about the method of teaching English using English songs. Finally, Students can learn and understand the use of tobe in the present tense form and past tense and get new vocabulary through the song. Not only knowing the meaning of the words in the song. However, students can also understand the true meaning of the song they are listening to. Through question and answer that is done after students listen to the song, students are also asked to dare to say the answer according to the questions given. Besides that songs as authentic material can make classes interesting and fun, increase students' interest in learning, provide everyday language exposure that is generally not displayed in textbooks, and integrate several language skills at once. One thing that teachers also need to pay attention to is the discussion of cultural aspects when instructors use songs in the classroom. In this study we can conclude.
\end{abstract}

\section{Keywords: Songs; Teaching; Simple Tobe; Simple Past Tense.}

\section{Introduction}

In everyday communication the tool that is often used to communicate is language, both in the form of written language and oral language. Language as a mean s of communication certainly has a function based on someone's needs consciously or unconsciously which he uses. (Parera 1993: 15). Language is a tool for expressing yourself, a communication tool, and a means for social control. Every society must have a language. Through language, humans can think and develop their knowledge.

In the current era of globalization English is a determining factor for taking over technology and supporting the process of communication and cooperation between countries in the world. Our country has established many cooperative relationships with foreign countries so it is only natural that English has experienced development in Indonesia. Along with this, the development of technology and science is currently required to be able to master English as an international language and is a communication tool between nations worldwide, in order to communicate and establish relationships with countries / nations that have different cultural and state backgrounds. 
For this reason, in the millennium, the British are increasingly felt urgent and very necessary considering that English is one of the international languages that is very commonly used in international relations in the fields of economics, trade, science, technology and information. For that English teaching should be introduced to Indonesian children early on.

A developing nation is a nation that wants to open itself to the development of the times. One form of time development experienced by the State of Indonesia is the development of technology and information, which cannot be denied from foreign countries. In order for our country to understand this information, we are required to learn and master the foreign languages that are used, namely English, so the Indonesian government has included English subjects into the curriculum, ranging from elementary to university level.

In learning English there are parts that must be considered, namely listening, speaking, reading, writing besides the important and main parts are grammar and vocabulary.

Grammar or grammatical structure is one of the most important aspects in English that must be learned and understood by everyone who wants to learn English. 'Learning a language applies to the conscious process of accumulating knowledge of vocabulary and grammar of the language '(Yule; 1987; 151). The fact shows that even though grammar from a foreign language has been taught but there are still many who are confused using it in the right grammar structure. 'ToBe' is an important part of English grammar.

Sometimes we hear students pronounce English sentences "I is a student" or "I a student" which is actually "I am a student". Or sometimes they ask something "is they from Jakarta?" Which is actually "are they from Jakarta?", And other evidence that we often encounter every day. This kind of problem is what we must pay attention to and must be dealt with serious about using the right grammar. There are many students just know and remember about 'ToBe' but they are still confused about using it because they do not fully understand about its use.

As we know that in Indonesian does not use 'ToBe'. For example, in Indonesian, 'Saya seorang siswa', in English, 'I am a student'. However, because it is affected by Indonesian, sometimes students translate 'I a student' not using 'ToBe'. Now this difference (English and Indonesian) makes students confused and makes it difficult for them to master the correct use of 'ToBe', which in the end there are number of students who are still incorrectly using 'ToBe'. Therefore the author tries to teach by using English songs to improve students' ability to master and understand the use of 'ToBe', especially Simple Present and Past Tense, and try to prove that with English songs / songs it is effective to improve the ability for students towards mastering 'ToBe'.

\section{Statement Of The Problem}

This research raises the problem "Is the use of songs or songs effective to improve students 'ability to master ToBe' in the form of Simple and Past Tense.

\section{Grammar}

As we know, that for proper and correct English, you must master the Grammar or English grammar in advance. English is very influenced by circumstances and governed 
by grammar. Brown (1993:347) stated : 'Grammar is a system of rules governing the conventional arrangement and relationship of words in a sentence'. So grammar discusses how to make sentences and gives instructions to string words into good sentences so that they can be understood and used to communicate easily and precisely. That's why we must understand grammar.

\section{Tense}

To deliver a purpose, wishes, statements, news, events, other actions, in writing or verbally so that they can be understood and understood clearly and correctly. When an event occurs, in English we must use the right and correct form of time (Tense). Tense is a form of verb in English to indicate the time (present, future, or past) of an action or event (Purnama: 2012). So Tenses are generally used to form a sentence in English based on the time of the event or event. An event or event can take place in the past or the Past, now or the Present and in the future or the Future.

To Be

To be consists of am, is, are while was and were the past form. Many interpret this to be as 'is' but in fact to be it is not interpreted in Indonesian. It should be remembered that to be used as a liaison between the subject and the predicate, so there is no meaning or can also be called an auxiliary word from a sentence. Let's look at the explanation in the following points.

\section{Definition of To Be}

- $\quad \mathbf{A m}=$ Used for the first person, pairs with 'I'

- Is = Used for a single third person, pairs with 'He, She, It'

- $\quad$ Are $=$ Used to show people who are more than one (plural) and the second person pairs with 'You, We, They'

Whereas was and were used for past or simple past tense forms.

- $\quad$ Was = It is the past form of am and is, paired with 'I, He, She, It'

- $\quad \mathbf{W e r e}=$ It is a past form of are, paired with 'You, We, They'

\section{The use of To be}

As we explained above, to be used as a link between subject and predicate. Now this predicate can be in the form of Adjective, Adverb, Noun, and Verb-Ing.

\section{To be + Adjective}

Adjective is a word that shows the nature of the subject or object. Example of sentence to be + Adjective is as follows.

$>$ I am Happy

\section{To be + Adverb}

Adverb is a word that describes the place and time the event occurred. Example of sentence to be + Adverb is as follows.

$>$ I am at home 


\section{To be + Noun}

Noun is a noun that shows an object, thing, animal, profession and so on that is around us. Example of sentence to be + noun is as follows: $>$ I am a writer (aku adalah seorang penulis)

\section{To be + Verb-ing}

To be + verb-ing this is one of the formulas of the Present Continuous Tense that is used to express an activity that is still ongoing or is being done. Example of sentence to be + verb-ing is as follows.

$>$ I am studying english

The use of the above sentence is a Present form, but if the context is in the past or past (Past) just change to be being / were

\section{Song}

The song is a very good 'tool' to help students learn English, more specifically songs are believed to be able to motivate students while following English learning. It can also be said that songs are an important part of learning English because songs make students more sensitive to sound, and learning languages is nothing but learning various types of sound that are meaningful. Songs can also make the class more interesting and lively. When children like the song taught by the teacher, they will be happy and enthusiastic to do it. And that's when, indirectly, they are learning something. According to Brewster et al. (2002: 162) There are many advantages to using songs as learning resources. First, the song is a linguistic resource. In this case the song becomes a medium for the introduction of new languages, as well as a medium for strengthening grammar and vocabulary. The song also presents the language that students have recognized in a new and fun form. The song also allows the repetition of language naturally and pleasantly. Songs can be used to develop all language skills integratively, including improving students' pronunciation skills.

Songs are affective / psychological resource. Besides being fun, the song is also able to motivate students while fostering a positive attitude towards English. Song is not a scary or threatening thing for students. Even songs can help increase students' confidence. As proof that they have mastered something in English, students can proudly sing English songs in front of their parents. Songs are cognitive resources. Songs help improve memory, concentration and coordination. Students become more sensitive to rima signs as a tool to interpret meaning. Songs can be a culture resource and social resource. Brewster et al. (2002) also revealed that songs provide extraordinary benefits for pronunciation learning. Some important pronunciation features such as stress and rhythm as well as intonation can be trained naturally through songs. 
Teaching ‘ToBe' English Using Songs

One of the most commonly used English language learning media is 'song' or singing. As an English teacher, the method of teaching English using songs is appropriate, we try one of the media in the learning process of English.

It is true, many methods of teaching English using song media. There are several steps in teaching English using songs as supported components. The following are the steps:

1. Students are played with songs that are very familiar or easily memorized in English.

2. Guessiing the lost vocabulary in song lyrics. This method is usually done in the classroom when the teacher wants to practice students' listening and writing skills. The trick, the teacher will share a piece of paper containing song lyrics with the parts intentionally left blank. Then, the teacher will play the song several times and ask students to listen carefully to the song. After that, students will be asked to fill in the blank verses according to the vocabulary they heard. This method is good enough to be applied because indirectly, students will learn to analyze sentences when guessing what words are empty in the stanza.

3. Ask students to sing the song in front of the class. Song, it turns out, can also be used as a means to train students' speaking skills. The teacher can assess the extent to which students are able to recite the English vocabulary while at the same time exercising their confidence in speaking in front of the class. This activity is quite fun because each student will get the opportunity to sing a song they like in front of the class. Later, other students will act as the 'jury' to check every word that is in the lyrics to determine the points of students sing in front. So, besides reciting the lyrics correctly, students are also required to memorize them.

4. Write down the overall song lyrics from the results of listening. This activity is a little more difficult than the two methods above. In this activity, students will be asked to write the lyrics they heard without help at all. This activity is effective to see the extent of students' ability in listening and also to check the spelling of students when writing the lyrics they hear.

And the songs used are as follows:

1. Are you sleeping Brother John

Are you sleeping, Are you sleeping

Brother Jhon, Brother Jhon

Morning bells are ringing

Morning bells are ringing

My Bonnie

The Beatles

My Bonnie lies over the ocean,

My Bonnie lies over the sea.

My Bonnie lies over the ocean.

Oh bring back my Bonnie to me.

My Bonnie lies over the ocean,

My Bonnie lies over the sea.

Well my Bonnie lies over the ocean.

Yeah bring back my Bonnie to me. 
Yeah bring back, ah bring back,

Oh bring back my Bonnie to me to me.

Oh bring back, oh bring back,

Oh bring back my Bonnie to me.

Well my Bonnie lies over the ocean,

My Bonnie lies over the sea.

Yeah my...

2. My Cock Is Dead

Round

My cock is dead

My cock is dead

My cock is dead

My cock is dead

He will never sing Co-co-di, co-co-da

He will never sing Co-co-di, co-co-da

Co-co-di, co-di

Co-co-di, coc-co-da

Co-co-di, co-di

Co-co-di, coc-co-da.

3. That is a Window

That is a window, that is a door

This is a blackboard and this is the floor

This is a table, that is the door

That is a desk and this is a floor

4. "Numbers"

When I was young

I went to school

And this is what I learn to do

One, two, three, four, five $3 \mathrm{x}$

I learn my numbers up to five

Six, seven, eight, nine, ten $3 x$

I learn my numbers up to ten

\section{Purpose Of The Research And Benefit Of The Research}

Purpose of the research

The purpose of this study was to see whether the use of English songs can improve students' understanding and mastery of Simple and Past Tense in affirmative sentences, denying and questioning sentences. And to prove that songs are also effective in increasing students' abilities in mastery 'To Be' Benefits of research

The results of the study are expected to be useful for researchers, students, lecturers and academics:

1. This research is expected to be useful for researchers to know precisely the conditions of the field, the problem of the learning process so that it becomes a reference in preparing before facing the actual conditions.

2. For students, the use of this method is expected to help them understand the lesson more easily and make them like English because the use of this method is fun. 
3. For readers, you will get information about the method of teaching English using English songs

\section{Research Method}

The study was conducted at St. Catholics Middle School. Mikael Manado for 4 months, starting from March to June 2019. The purpose of this study was to find out the use of effective songs or songs to improve students 'abilities in ToBe mastery' in the form of Simple and Past Tense. at St. Catholic Middle School Mikael Manado.

In this study qualitative descriptive research was used. Qualitative descriptive research is a type of qualitative research where the objects studied, people, institutions and others are presented in actual terms in the present. This research emphasizes the meaning and focuses on quality data with the process of occurrence. Data collection in this study uses the method of observation, interviews, and reviewing documentation and archives. In this study used data source triangulation techniques and theory triangulation techniques, where the author collects various data which is then associated with theories obtained from the implementation of English Language Learning u sing song media at St. Catholics Middle School. Mikael Manado. It is believed that the facts, data and information obtained can be accounted for validity and reliability. Then checks through sources by comparing data from observations and interviews with informants. The data analysis technique in this study used a qualitative / descriptive descriptive analysis model.

2. Population and Sample

a. Population

The population in the study of English learning using this song is the Catholic Middle School St. Mikael Manado grade VII which consists of three classes A, B, C.

b. Sample

The sample in the study of English learning using this song is the Catholic Middle School St. Mikael Manado grade VII class B which consists of 36 students / i.

\section{Results And Outputs Achieved}

Discussion and Results

Discussion

One thing that needs to be underlined in teaching and learning activities is that both students and teachers must engage in pleasant interactions. Teachers and students alike form a condition that supports learning activities. Before starting teaching and le arning activities, the teacher must be prepared with the material to be given to students. Likewise with students, they must be ready to accept the material to be given by the teacher. Furthermore, the factors that also influence teaching and learning activities are the environments in which these teaching and learning activities are held. The thing that often becomes a problem is when these three factors are not fulfilled properly.

Problems in teaching and learning activities can be overcome by interesting learning methods. Thus, students will take the lessons without feeling burdened. Teachers are indeed required to innovate in making appropriate learning methods in accordance with the Basic Competencies that must be met.

First the teacher can choose which song is suitable for learning or not. When choosing songs as authentic material for English learning activities, there are a number of things that the teacher needs to consider. 
First, the teacher needs to access various songs and download them easily. Websites like Youtube or AZLyrics and applications such as Joox or Spotify are practical choices that teachers can try when searching for songs and their ly rics. There are 7 songs used in this study which are songs that are familiar to middle school students.

The most common learning method that is fun but still adds knowledge is to use songs. The use of songs in English learning activities is actually not new. There are many English-language songs ranging from fast tempo songs that are sometimes difficult to follow to slow tempo songs that can be easily followed.

Second, the instructor needs to study the syllabus and look for topics / sessions that allow it to be discussed using songs. For example, if there is one topic of Tobe Present Tense, the song Are You sleeping can be used because the song shows the use of to be Present Tense 'are '. Teachers can also show the tobe used in present ten se other than are namely, am. And the use of the 'ToBe'.

Usage Table to Be Present (present)

\begin{tabular}{|ll|}
\hline To be & Subjek \\
\hline am & I \\
are & You \\
& They \\
& We \\
is & She \\
& He \\
& It \\
\hline
\end{tabular}

Tabel Penggunaan to Be Past (masa lampau)

$\begin{array}{ll}\text { To be } & \text { Subjek } \\ & \text { I } \\ \text { Was } & \text { She } \\ & \text { He } \\ & \text { It } \\ & \text { You } \\ \text { Were } & \text { They } \\ & \text { we }\end{array}$

Third, the teacher needs to choose songs that are in accordance with the children's level. Song speed, the complexity of the lyrics, song content, and language style are things that generally influence teacher decisions. For example, if the instructor teaches English classes for children, the selected song should be a simple song and contain s a message that fits their age.

Fourth, teachers need to design communicative and interesting activities for students. For example, the teacher changes the subject that is on the song and the students can express the song through the movement by composing the subject of the song lyrics, along with the subject changes, Tobe will be adjusted to the subject given by the teacher, then the teacher gives the opportunity to discuss how to change the song From the present tense form to past tense and the meaning of songs and telling students to create their own version of the lyrics using the right subject and subject, etc. 
After the teacher has played the song to the students, the teacher can give questions according to the contents of the song. If students can answer these questions correctly, students are able to hear and understand the contents of the song. Another way that can be used is the teacher playing the song then the students write the lyrics of the song. The teacher can play the song by dividing it into several parts so that students are not deterred from writing the lyrics of the song.

Another way to use songs to improve the ability to understand to be persent and past tense English is by the way students sing the song then the teacher tells the singer to sing the song by using changes in the lyrics changes that have been made by the teacher, for example the song is titled "where thumkin" song this is in the form of present instructors telling them to put it in a past form and replace the following words:

Thumbkin became thumbkins

I became we and they

After that

Thumbkin became Cat

$I$ became it, she and it.

\section{Where is Thumbkin}

Where is thumbkin $2 \mathrm{x}$

Here I am 2x

How are you today sir

Very well thank you

Run away.... run away...

Students who sing the song. To make the atmosphere more interesting, the te acher can also appoint other students to host and also jurors like a singing contest. Then the teacher asks to change the song that has been given in the form of past tense.

And also make / change each subject. And after students change it, the teacher tells a finished student to sing in front of the class. Teachers can save a lot of time by utilizing existing activities, but teachers can certainly be self-creative if needed.

In this kind of teaching students are trained in their understanding of the topic given their participation or activity and their courage to appear in front of the class.

\section{Conclusion And Suggestion}

Conclusion of songs for learning English. Various studies and articles have also proven that songs are mean to attract students' interest in learning English. Students can learn and understand the use of tobe in the present tense form and past tense and get new vocabulary through the song. Not only knowing the meaning of the words in the song. However, students can also understand the true meaning of the song they are listening to. Through question and answer that is done after students listen to the song, students are also asked to dare to say the answer according to the questions given. Besides that songs as authentic material can make classes interesting and fun, increase students' interest in learning, provide everyday lan guage exposure that is gen erally not displayed in textbooks, and integrate several language skills at once. One thing that 
teachers also need to pay attention to is the discussion of cultural aspects when instructors use songs in the classroom. In this study we can conclude. The following is a conclusion from this study.

a. The application of English-language songs is effective to improve students' abilities in ToBe mastery in the form of Simple and Past Tense and enrich vocabulary.

b. From the results obtained in this study, proving that the method used, namely using English songs can increase the ability of students in the ToBe mastery 'in the form of Simple and Past Tense and enriching vocabulary is very effective.

The implementation of learning and teaching activities must be synchronized with the objectives and the right media in its implementation. So as educators, we are required to continue to quality ourselves in order to be able to provide material that is packaged in interesting and appropriate media to facilitate the achievement of le arning objectives.

\section{BIBLIOGRAPHY}

Brown, H douglas. 2004. Language Assessment. United Stated Of America: San Francisco State University.

Ismawati, Esti. 2011. Metode Penelitian Pendidikan Bahasa dan Satra. Surakarta: Yuma Pustaka.

Lorenzutti, N. (2014). Beyond the gap fill: dynamic activities for song in the EFL classroom.

Miarso, Y. 20041. Menyemai Benih Teknologi Pendidikan. Jakarta : Prenada Media.

Nurhayati. 2009. "Developing English Skills through Songs and Music", The 2009

UAD TEFL National Conference (Proceeding).

Sari, R. 2009. “Teaching Grammar: Does It Need Extraordinary Teaching?”, The 56th TEFLIN International Conference (Program Book).

Suwartono. 2012. "Songs Helped Them Learn the English Connec ted Speech", 